\title{
Odwołania do szkół filozoficzno-prawnych w uzasadnieniach orzeczeń polskich sądów
}

\section{Wprowadzenie}

Praktyka posiłkowania się przez sądy dorobkiem filozofii prawa w procesie stosowania prawa, czy też zjawisko determinowania tego procesu przez założenia filozoficzno-prawne bliskie członkom składu orzekającego zostały dostrzeżone przez rodzimą doktrynę prawniczą. Pod tym kątem poddano naukowej eksploracji w szczególności orzecznictwo Trybunału Konstytucyjnego (dalej: „TK”)2. Problematyką natomiast zasadniczo jedynie sygnalizowaną w polskiej jurysprudencji jest sięganie przez sądy do założeń partykularnych kierunków filozofii prawa bezpośrednio w tekstach orzeczeń. Ze względu na ekstraordynaryjność takich przypadków, „bezpośrednią infiltrację do uzasadnień sądowych określonej koncepcji filozoficzno-prawnej” postrzega się jako coś „,bezprecedensowego"3.

$\mathrm{Z}$ jednej strony, zasadnemu przekonaniu przedstawicieli nauki prawa o „tym, iż filozofia prawa przydatna jest również w procesie stosowania prawa” towarzyszy z drugiej strony spostrzeżenie, że: „uwzględnianie wiedzy filozoficzno-prawnej w procesie stosowania prawa, co powinno znajdować odzwierciedlenie w uzasadnieniach orzeczeń, nie jest jednak wprost zaznaczane"4. Rzadko reprezentanci doktryny prawniczej oczekują odniesień do szkół filozoficzno-prawnych w uzasadnieniach konkretnych orzeczeń, a ich brak w judykacie staje się powodem zarzutu czynionego sądom ${ }^{5}$.

Zagadnienie relacji łączących sędziego, w szczególności sędziego sądu konstytucyjnego, z filozofem oraz upatrywania w szeroko rozumianej filozofii źródła inspiracji i argumentów dla sędziów, jest w nauce prawa kojarzone zwłaszcza z koncepcją „sędziego

Numer ORCID: 0000-0002-3861-9103. Adres e-mail: gmaron@ur.edu.pl

Np. J. Potrzeszcz, Idea prawa w orzecznictwie polskiego Trybunatu Konstytucyjnego, Lublin 2007; K. Działocha, W. Gromski, Niepozytywistyczna koncepcja państwa prawnego a Trybunat Konstytucyjny, „Państwo i Prawo” 1995/3, s. 4-16; L. Morawski, Spór o pojęcie państwa prawnego, „Państwo i Prawo” 1994/4, s. 3-12.

3 J. Zajadło, Po co prawnikom filozofia prawa?, Warszawa 2008, s. 66; W. Łączkowski, Filozofia prawa a instytucja Trybunatu Konstytucyjnego, w: B. Czech (red.), Filozofia prawa a tworzenie i stosowanie prawa, Katowice 1992, s. $227-232$.

4 A. Kalisz, M. Stefaniuk, Filozofia prawa w polskiej edukacji prawniczej w pierwszej dekadzie XXI wieku, w: A. Orłowska, P. Polaczuk, L. Świto (red.), Filozofia a praktyka prawnicza, Olsztyn 2010. O doniosłości filozofii prawa dla orzecznictwa zob. także I.S. Grat, Stanowisko prawnonaturalne Czestawa Strzeszewskiego na tle pogladów polskich tomistów, Białystok 2009, s. 57.

5 J. Zajadło, Pięć minut antyfilozofii antyprawa. Glosa do uchwały SN z dnia 20 grudnia 2007 r., I KZP 37/07, „Gdańskie Studia Prawnicze. Przegląd Orzecznictwa” 2008/1, s. 161-173. 
Herkulesa" autorstwa Ronalda Dworkina ${ }^{6}$. R. Dworkin nie był pionierem eksponującym potrzebę posiadania przez sędziego przymiotów filozofa. Dla rodaka Dworkina, Cuthberta Pounda, sędzia powinien być ,zarówno prawnikiem, jak i filozofem najwyższej klasy, obdarzonym zdrowym rozsądkiem i praktycznym doświadczeniem"7. Takie samo przeświadczenie było udziałem Szymona Rundsteina, który przekonywał, że jakkolwiek „sędziowie nie są filozofami zawodowymi”, to „funkcje które sprawują zmuszają ich niejako do filozoficznego ujmowania wytworów prawnych, którymi operują". Równo 70 lat po cytowanej wypowiedzi S. Rundsteina, Marek Safjan postawił wymowne pytanie: „sędzia filozof” czy „sędzia pozytywista (rzemieślnik)”??

Zamierzeniem stojącym u podstaw opracowania jest zaprezentowanie rezultatów analizy uzasadnień orzeczeń polskich sądów pod kątem obecności w nich odwołań do filozofii prawa, a konkretnie do poszczególnych szkół filozoficzno-prawnych. Sprofilowanie przedmiotu badań w ten sposób bynajmniej nie suponuje, że udział argumentacji filozoficzno-prawnej w procesie orzeczniczym ogranicza się jedynie do przypadków, gdy sąd następnie w uzasadnieniu orzeczenia argumentację tę ujawni i wprost nazwie konkretny kierunek filozoficzno-prawny do którego założeń sięgnął. Tekst uzasadnienia zwykle nie jest w pełni wiernym odzwierciedleniem przebiegu aktu sądowej deliberacji ${ }^{10}$. Nieobecność w uzasadnieniu nawiązań do dorobku filozofii prawa nie oznacza, że: „problematyka filozoficzno-prawna nie jest brana pod uwage" 11 .

Opracowanie jest głównie jakościowej natury. Służy scharakteryzowaniu tytułowej praktyki sądów, w rozumieniu usystematyzowania odwołań do kierunków filozoficzno-prawnych i rozpoznania prawidłowości znamionujących posługiwanie się przez sądy tymi odwołaniami. Przeprowadzone studium orzecznictwa pozwoliło jednak też na sformułowanie wniosków odnośnie do ilościowej strony omawianej praktyki, czyli w kwestii skali, intensywności i dynamiki przypadków przywoływania szkół filozoficzno-prawnych w uzasadnieniach orzeczeń z podziałem na poszczególne typy sądów.

Zakresem analizy objęto przypadki bezpośredniego i literalnego wzmiankowania przez sąd w uzasadnieniach orzeczeń konkretnych kierunków filozoficzno-prawnych. Przez tytułową szkołę filozoficzno-prawną rozumiem najogólniej intelektualny kierunek wyodrębniony w jurysprudencji, dla którego właściwy jest pewien całościowy ogląd bądź projekcja prawa, czy porządku prawnego w ujęciu deskryptywnym i/lub normatywnym.

Za materiał badawczy posłużyły orzeczenia sądów powszechnych, sądów administracyjnych, Sądu Najwyższego (dalej: „SN”) i Trybunału Konstytucyjnego ${ }^{12}$, zgromadzone w elektronicznej bazie orzeczeń wchodzącej w skład Systemu Informacji Prawnej LEX $^{13}$. W rozważaniach uwzględniono orzeczenia z lat 1990-2019, czyli z okresu III $\mathrm{RP}^{14}$. Orzeczenia przywołujące szkoły filozoficzno-prawne wstępnie identyfikowano

\footnotetext{
R. Dworkin, Imperium prawa, Warszawa 2006.

C.W. Pound, Defective Law - Its Cause and Remedy, „New York State Bar Association Bulletin” 1929/9, s. 285.

S. Rundstein, Zagadnienia teorii prawa w orzecznictwie cywilnym Sądu Najwyższego, „Palestra” 1937/12, s. 1050.

M. Safjan, Wyzwania dla państwa prawa, Warszawa 2007, s. 202-208; J. Zajadło, Sędzia konstytucyjny - profil filozoficznoprawny, w: W. Staśkiewicz, T. Stawecki (red.), Dyskrecjonalność w prawie, Warszawa 2010, s. 20.

10 O sędziowskiej szczerości w kontekście uzasadnień orzeczeń zob. G. Maroń, Integralność religijna sędziego oraz argumentacja religijna w amerykańskim procesie orzeczniczym, Rzeszów 2018, s. 359-376.

11 A. Kalisz, M. Stefaniuk, Filozofia ..., s. 21.

12 Jakkolwiek Trybunał Konstytucyjny nie jest sądem sensu stricto i nie sprawuje wymiaru sprawiedliwości, niemniej jednak jest organem typu sądowego (organem władzy sądowniczej).

13 https://sip.lex.pl

14 W zasobach bazy LEX zgromadzono 2156008 orzeczeń z lat 1990-2019, tj. 11472 orzeczeń TK, 117445 orzeczeń SN, 1390802 orzeczeń wojewódzkich sądów administracyjnych, 282287 orzeczeń Naczelnego Sądu Administracyjnego (dalej:
} 
poprzez wyszukiwarkę bazy LEX, jako wyszukiwane hasła podając nazwy lub dystynktywne fragmenty nazw szkół filozoficzno-prawnych najczęściej wyróżnianych w nauce prawa $^{15}$. Judykaty wskazane jako rezultaty wyszukiwanych haseł poddano następnie ocenie kontekstualnej, w celu zweryfikowania czy rzeczywiście zawierają nawiązania do szkoły filozoficzno-prawnej i czy można przypisać je sądowi. Z dalszej analizy odrzucono więc te początkowo wyselekcjonowane orzeczenia, w których jakkolwiek pojawiają się określenia zbieżne z nazwami kierunków filozoficzno-prawnych, to jednak posiadające inne znaczenie, np. gdy terminem „prawo naturalne” (,prawo natury”) posłużono się w rozumieniu praw biologicznych lub praw fizyki, a wyraz „normatywizm” utożsamiono z normatywnością, a nie koncepcją Hansa Kelsena. W ustaleniach ilościowo-jakościowych pominięto też orzeczenia, w uzasadnieniach których wzmiankowano poglądy doktryny prawniczej, gdzie to cytowani przez sąd autorzy, a nie sam sąd, nawiązywali do szkół filozoficzno-prawnych ${ }^{16}$. Poza zakresem badań pozostawiono również judykaty, w których sądy sprawozdawczo odnotowały przypadki odwoływania się do szkól filozoficzno-prawnych przez strony postępowania ${ }^{17}$. Pominięto także orzeczenia, gdzie wzmianki z zakresu filozofii prawa pozostawały w ścisłym związku z przedmiotem sprawy ${ }^{18}$. Z zakresu właściwej analizy wyłączono ponadto orzeczenia, w których nawiązania do szkół filozoficzno-prawnych były częścią innych cytowanych orzeczeńn ${ }^{19}$.

Poza ramami przeprowadzonego studium orzecznictwa znalazły się orzeczenia, w których jakkolwiek niewątpliwie sięgnięto do twierdzeń właściwych dla konkretnej szkoły filozoficzno-prawnej, to jednak bez przywołania z nazwy samej tej szkoły. Przykładowo, pojmowanie prawa uwzględniające założenia szkoły historycznej w prawoznawstwie dostrzec można w jednym z wyroków TK, gdy sąd konstytucyjny stwierdza, że prawo to nie tylko „zbiór ustanowionych zgodnie z formalnie określoną procedurą przepisów”, ale także „zespół aksjologicznie i celowościowo powiązanych norm, stanowiący wytwór kulturowy, zakorzeniony w doświadczeniach historycznych wspólnoty i budowany w oparciu o wspólny dla danego kręgu podmiotów system wartości"20. Przywołanie przez Sąd Okręgowy (dalej: „SO”) w Częstochowie twierdzenia Arthura Kaufmanna, że „nie ma prawa przed wykładnią” jest wyraźnym nawiązaniem do hermeneutyki prawniczej ${ }^{21}$. Za odwołanie do szkoły prawa naturalnego bez literalnego

„NSA”), 36880 orzeczeń NSA (sprzed jego reformy do końca 2003 r.), 860034 orzeczeń sądów rejonowych, 152319 orzeczeń sądów okręgowych, 78722 orzeczeń sądów apelacyjnych i 48 orzeczeń sądów wojewódzkich. Dane na dzień: 24.04.2020 r.

15 Wyszukiwanymi szkołami filozoficzno-prawnymi były: pozytywizm prawniczy, normatywizm prawny, jusnaturalizm, realizm prawny, szkoła historyczna w prawoznawstwie, hermeneutyka prawnicza, psychologizm prawniczy, socjologiczna jurysprudencja, szkoła wolnego prawa (orzecznictwa), ekonomiczna analiza prawa, postmodernizm prawniczy, krytyczna teoria prawa, integralna teoria prawa, feministyczna teoria prawa, marksistowska teoria prawa, analityczna filozofia prawa, autopojetyczna teoria prawa. Za bezpośrednie odwołanie się do jusnaturalizmu potraktowano także przypadki obecności w uzasadnieniach orzeczeń nawiązań do „prawa naturalnego”, „prawa natury”, „prawa przyrodzonego”. Por. J. Oniszczuk, Filozofia i teoria prawa, Warszawa 2012, s. V-X.

16 Np. wyrok Sądu Administracyjnego (dalej: „SA”) w Białymstoku z 10.09.2015 r. (I ACa 355/15), LEX nr 1808630 (ekonomiczna analiza prawa); wyrok Wojewódzkiego Sądu Administracyjnego (dalej: „WSA”) w Warszawie z 10.05.2006 r. (II SA/Wa 259/06), LEX nr 257149 (hermeneutyka prawnicza).

17 Np. postanowienie SO w Lodzi z 4.12.2014 r. (III Ca 1030/14), LEX nr 2126516 (normatywizm Hansa Kelsena); wyrok WSA w Gliwicach z 17.08.2016 r. (I SA/Gl 257/16), LEX nr 2120471 (hermeneutyka prawnicza).

18 Przykładowo, w sprawie dotyczącej przyznania stypendium dla najlepszych doktorantów, sąd w uzasadnieniu orzeczenia wskazał, że skarżący opublikował artykuł naukowy dotyczący „iusnaturalizmu” i ,iuspozytywizmu”. Wyrok WSA w Warszawie z 16.01.2015 r. (II SA/Wa 1051/14), LEX nr 1747038. Zob. też wyrok WSA w Warszawie z 29.03.2019 r. (II SA/Wa 1306/18), LEX nr 2771050 (analityczna filozofia prawa).

19 Wyrok WSA w Warszawie z 12.06.2015 r. (III SA/Wa 2304/14), LEX nr 1972009.

20 Wyrok TK z 30.09.2008 r. (K 44/07), OTK-A 2008/7, poz. 126.

21 Postanowienie SO w Częstochowie z 29.11.2013 r. (IV U 1251/10), LEX nr 1867681. 
jej nadmienienia można z kolei potraktować sięgnięcie przez sądy do tzw. formuły Radbrucha $^{22}$ czy do wewnętrznej moralności prawa Lona Fullera ${ }^{23}$.

\section{Odwołania do szkół filozoficzno-prawnych w ujęciu ilościowym}

Przy przyjętych założeniach konceptualnych i metodologicznych odwołania do szkół filozoficzno-prawnych rozpoznano łącznie w 101 orzeczeniach i 7 zdaniach odrębnych. Orzeczenia te stanowią proporcjonalnie bardzo niewielki, wręcz znikomy ułamek wszystkich judykatów, liczony w setnych promila $(\approx 0,05 \%$ ). Odniesienia do kierunków filozoficzno-prawnych pojawiają się w uzasadnieniach orzeczeń autorstwa nie tylko Trybunału Konstytucyjnego i Sądu Najwyższego, ale także - i to częściej, mierząc w liczbach bezwzględnych - sądów powszechnych i administracyjnych. Nawiązania do konkretnych szkół filozoficzno-prawnych stwierdzono w 13 orzeczeniach TK i 6 zdaniach odrębnych sędziów TK, 7 orzeczeniach SN i jednym zdaniu odrębnym sędziego SN, 66 orzeczeniach sądów powszechnych i 15 orzeczeniach sądów administracyjnych. W odniesieniu do orzeczeń sądów powszechnych należy odnotować, że na łącznie 66 judykatów aż 42 stanowity wyroki i postanowienia SO w Częstochowie, przy czym fragmenty ich uzasadnień zawierające odniesienia do szkół filozoficzno-prawnych były tekstowo identyczne.

W ostatniej dekadzie można zaobserwować intensyfikację odniesień do kierunków filozoficzno-prawnych w uzasadnieniach orzeczeń, zwłaszcza sądów powszechnych i administracyjnych, lecz tylko jeśli mierzyć ją w liczbach bezwzględnych. Przed 2000 r. odniesienia takie pojawiają się w zaledwie dwóch orzeczeniach TK i dwóch zdaniach odrębnych sędziów TK oraz jednym orzeczeniu SN. W latach 2000-2009 odnotowano 20 orzeczeń i trzy zdania odrębne zawierające literalne nawiązania do kierunków filozoficzno-prawnych. Z kolei w latach 2010-2019 orzeczeń tego typu było 79 plus dwa zdania odrębne. W ujęciu proporcjonalnym odniesienia do szkół filozoficzno-prawnych rozpoznano w $0,137 \%$ \% $0,044 \%$ o i 0,051\%o judykatów odpowiednio z lat 1990-1999, 2000-2009 i 2010-2019 zgromadzonych w bazie LEX. Podanych wskaźników nie sposób jednak traktować jako w pełni miarodajne dla określenia dynamiki tytułowego zjawiska z racji tego, że wykorzystana baza orzeczeń, zwłaszcza starszych orzeczeń sądów powszechnych i SN, jest fragmentaryczna ${ }^{24}$.

Nawiązania do szkół filozoficzno-prawnych w uzasadnieniach orzeczeń mają w dużym stopniu charakter bipolarny, ogniskując się wokół dwóch konkurencyjnych kierunków, tj. pozytywizmu prawniczego, w tym normatywizmu, i jusnaturalizmu (92 orzeczenia i 7 zdań odrębnych). W uzasadnieniach do zaledwie 10 orzeczeń pojawiają się literalne odwołania do innych szkół filozoficzno-prawnych.

\section{Przegląd szkół filozoficzno-prawnych przywoływanych w judykatach}

Zdecydowana większość (ponad 91\%) przypadków odwoływania się przez sądy w uzasadnieniach orzeczeń do kierunków filozoficzno-prawnych dotyczy - jak już wskazano

\footnotetext{
22 Wyrok WSA w Warszawie z 3.08.2016 r. (VII SA/Wa 1592/15), LEX nr 2138028. Zob. też zdanie odrębne sędzi E. Łętowskiej do wyroku TK z 27.10.2010 r. (K 10/08), OTK-A 2010/8, poz. 81; wyroki SO w Częstochowie z: z 31.05.2019 r. (IV U 241/19), LEX nr 2704111; 8.08.2019 r. (IV U 313/19), LEX nr 2725361; 25.10.2019 r. (IV U 1607/19), LEX nr 2754726; 30.07.2019 r. (IV U 99/19), LEX nr 2739631; 30.07.2019 r. (IV U 610/19), LEX nr 2735234. Abstrahuję od doktrynalnej debaty w przedmiocie tego, czy powojenny Gustaw Radbruch to w pełni jusnaturalistyczny konwertyta. Zob. orzeczenia SO w Częstochowie podane w przypisie 37.

24 Baza LEX zawiera 36466 orzeczeń omawianych kategorii sądów z lat 1990-1999, 522703 orzeczeń z lat 2000-2009 i 1596839 orzeczeń z lat 2010-2019 (dane na dzień: 24.04.2020 r.).
} 
wyżej - pozytywizmu prawniczego i jusnaturalizmu, czyli dwóch najbardziej znanych i jednocześnie pozostających względem siebie w opozycji szkół w jurysprudencji.

W sposób aprobatywny, czy nawet apologetyczny na twierdzenia pozytywizmu prawniczego powołano się expressis verbis $\mathrm{w}$ zaledwie czterech orzeczeniach i trzech zdaniach odrębnych. Do niniejszej szkoły sięgnięto w kontekście obowiązywania prawa, systemu źródeł prawa, odtwórczego charakteru wykładni prawa czy przebiegu procesu stosowania prawa.

Wojewódzki Sąd Administracyjny w Gdańsku nawiązując do pozytywizmu, opowiedział się za formalnym uzasadnieniem obowiązywania prawa, jednocześnie odrzucając kryteria słusznościowe i empiryczne w ustaleniach walidacyjnych, bliskie z kolei szkole prawa naturalnego i realizmu prawnego. W ocenie sądu:

Na gruncie teorii prawa pojęcie obowiązywania przepisów prawa jest pojęciem wieloznacznym, można je bowiem rozpatrywać bądź pod względem normatywnym, faktycznym czy aksjologicznym. Mając jednak na względzie, że polski system prawny opiera się na założeniach pozytywistycznej koncepcji prawa, należy przyjąć, że w jego ramach dany przepis należy uznać za obowiązujący o ile obowiązuje on w sensie normatywnym tzn. został on prawidłowo ustanowiony i nie został jak dotąd uchylony, niezależnie od tego czy można go także uznać za obowiązujący w sensie faktycznym (zgodnie z tą koncepcją obowiązują tylko te normy, które są faktycznie stosowane przez organy państwowe) oraz w sensie aksjologicznym (zgodnie z tą koncepcją obowiązują tylko te normy, które spełniają określone kryteria etyczne $)^{25}$.

Dlatego też nawet, ,jeżeli określony przepis ustawy podatkowej jest w społecznym odczuciu postrzegany jako niesprawiedliwy, krzywdzący czy nielogiczny, musi on zostać zastosowany przez organy w każdym przypadku wypełnienia jego hipotezy"26.

Wojewódzki Sąd Administracyjny w Bydgoszczy przedstawił „pozytywistyczną wykładnię prawa" jako gwarancję chroniącą przed sądowym prawotwórstwem ${ }^{27}$. Jeszcze inny sąd administracyjny, WSA w Gorzowie Wielkopolskim, z pozytywizmem złączył „rozróżnienie etapów ustalania faktów i ich oceny od subsumpcji”28. Z kolei sędzia Barbara Wagner w zdaniu odrębnym do jednej z uchwał SN podniosła, że status porozumień zawieranych między związkami zawodowymi i pracodawcą lub organizacjami pracodawców, jako źródeł prawa pracy, należy rozpatrywać na ,płaszczyźnie normatywistycznego rozumienia prawa (na gruncie pozytywistycznej koncepcji prawa) i odnoszone do obowiązującego systemu norm prawnych"29.

Bardziej rozbudowane rozważania filozoficzno-prawne w obronie pozytywizmu i w opozycji do jusnaturalizmu poczynił w orzecznictwie Kazimierz Działocha w jednym ze zdań odrębnych do orzeczenia TK. Sędzia akceptując czerpanie z „doktryn prawa natury” do „oceny słuszności moralnej prawa pozytywnego”, jednocześnie krytycznie odnosi się do posługiwania się nimi do „rozwiązywania konkretnych problemów, związanych z obowiązywaniem i wykładnią prawa”. W ocenie sędziego coraz częściej w dyskursie prawniczym: „W rozważaniach na temat kwestii walidacyjnych i interpretacyjnych z niezwykłą łatwością i dużą niefrasobliwością operuje się sloganem «lex iniusta non est lex», traktując tę formułę jako swoistą regułę kolizyjną lub klauzulę derogacyjną”. K. Działocha podnosi, że wspomniana formuła jest niereprezentatywna

Wyrok WSA w Gdańsku z 18.01.2006 r. (I SA/Gd 994/03), LEX nr 709667.

26 Wyrok WSA w Gdańsku z 11.09.2008 r. (I SA/Gd 254/08), LEX nr 465809.

27 Wyrok WSA w Bydgoszczy z 11.05.2011 r. (II SA/Bd 311/11), LEX nr 1132144.

28 Wyrok WSA w Gorzowie Wielkopolskim z 7.08.2008 r. (I SA/Go 557/08), LEX nr 487167.

29 Zdanie odrębne sędzi B. Wagner do uchwały składu siedmiu sędziów SN z 23.05.2001 r. (III ZP 25/00), OSNP 2002/6, poz. 134 . 
dla jusnaturalizmu, grożąc sprowadzeniem „całych, nierzadko bardzo wyrafinowanych, koncepcji prawa natury do pozornie nieskomplikowanego schematu, który wyrażać ma cytowany tutaj slogan”. Formuła ta paradoksalnie szkodzi jusnaturalistom. Dostarcza bowiem argumentów „zwolennikom pozytywizmu prawniczego, którzy biorąc za przedmiot swoich ataków tę właśnie uproszczoną, zredukowaną wersję koncepcji prawa natury wyjątkowo łatwo ujawniają wszelkie jej słabości, a nawet absurdalność”. Powołując się na Johna Finnisa, sędzia artykułuje „moralny obowiązek przestrzegania obowiązującego prawa, niezależnie od jego krytycznej oceny". Troska o skuteczność systemu prawnego przemawia w przekonaniu K. Działochy za „niepodważalnością (...) pozytywistycznie zorientowanej koncepcji prawa"30.

Aprobatywnie do związanego z pozytywizmem nonkognitywizmu nawiązał w zdaniu odrębnym do jednego z wyroków TK sędzia Bohdan Zdziennicki. W kontekście tzw. ustawy lustracyjnej stwierdził, że: „Zakres faktów podlegających ujawnieniu wynika z woli ustawodawcy, która może ulegać przemianom. Prawo pozytywne nie może zaś kreować «prawdy» lub «fałszu» w znaczeniu prawnonaturalnym (absolutnym). Kwestionowana ustawa musi być zawsze interpretowana w duchu prawa pozytywnego a nie prawa naturalnego (absolutnego)"31.

Częściej sądy pozytywizm prawniczy poddawały krytyce (39 orzeczeń i 2 zdania odrębne). Zwykle kwestionowały łączone z nim: sylogistyczny model stosowania prawa, prymat a nawet wyłączność wykładni językowej w ramach wykładni operatywnej, sprawiedliwość legalną, utożsamianie prawa z przepisami prawnymi oraz rozdział prawa i moralności.

Sąd Okręgowy w Opolu w atencji prokuratury do pozytywizmu prawniczego doszukał się powodów reglamentacyjnego rozumienia przez nią wolności zrzeszania się. „Niestety, do dzisiaj «pokutuje» szkoła pozytywizmu prawniczego - czego efektem wydaje się być apelacja Prokuratora - zakładająca, że wszystko co człowiek może uczynić, musi mieć oparcie w prawie stanowionym przez państwo. Konsekwencją tego jest właśnie utożsamianie pojęć «prawo jednostki» $\mathrm{Z}$ «wolnością jednostki»”, gdy tymczasem Konstytucja RP z 1997 r. ${ }^{32}$ „odeszła od pozytywistycznego "prawa do zrzeszania się»"

W zdaniach odrębnych do dwóch orzeczeń TK Marian Zdyb potępił absolutyzację formalnego uzasadnienia obowiązywania prawa, legalistyczne rozumienie sprawiedliwości i kelsenowską separację prawa i moralności. W jego przekonaniu:
Nieraz już, skrajnie pozytywistyczna idea prawa prowadziła do owego już symbolicznego radbruchowskiego ustawowego bezprawia. Takie niebezpieczeństwa pojawiają się zwłaszcza wtedy gdy aksjologiczne podstawy obowiązującego porządku prawnego nie są czytelne albo gdy prawo w tej materii milczy lub jest niewystarczające. Proceduralna nadwrażliwość, pro- wadzi wtedy do kelsenowskiej tezy, że każda dowolna treść może być treścią prawa, byle tylko procedury zostały zachowane ${ }^{34}$.

Według M. Zdyba „konieczne jest wyjście poza skrajnie pozytywistyczną optykę widzenia prawa" 35 .

\footnotetext{
Zdanie odrębne sędziego K. Działochy do postanowienia TK z 7.10.1992 r. (U 1/92), OTK 1992/2, poz. 38.

1 Zdanie odrębne sędziego B. Zdziennickiego do wyroku TK z 28.05.2003 r. (K 44/02), OTK-A 2003/5, poz. 44.

2 Konstytucja Rzeczypospolitej Polskiej z 2.04.1997 r. (Dz. U. Nr 78, poz. 483 ze zm.), dalej: „Konstytucja RP”.

3 Postanowienie SO w Opolu z 7.09.2012 r. (VI Ga 118/12), LEX nr 1890209.

34 Zdanie odrębne sędziego M. Zdyba do wyroku TK z 23.02.1999 r. (K 25/98), OTK 1999/2, poz. 23. Podobnie, zdanie odrębne sędziego M. Zdyba do wyroku TK z 24.06.1998 r. (K 3/98), OTK 1998/4, poz. 52. O kelsenowskim modelu systemu prawa zob. wyrok WSA w Warszawie z 23.08.2019 r. (VI SA/Wa 1051/19), LEX nr 2865910.

35 Zdanie odrębne sędziego M. Zdyba od orzeczenia TK z 9.06.2003 r. (SK 5/03), OTK-A 2003/6, poz. 50.
} 
Sprzeciw sądów budził pozytywistyczny ogląd procesu wykładni i stosowania prawa, a przynajmniej łączony czy kojarzony z pozytywizmem prawniczym. Sąd Apelacyjny w Gdańsku zwrócił uwagę na to, że:

Stosowanie reguł egzegezy teksu nie jest niezależne od uwarunkowań kulturowych i czy ideologicznych (...) Przykładowo w doktrynie pozytywistycznej nie ulegało wątpliwości, że niedopuszczalna jest wykładnia contra legem czy też odstępowania od zasady clara non sunt interpretanda. Współcześnie trudno byłoby zaaprobować odstąpienie od zasady niedopuszczalności wykładni contra legem rozumianej w ten sposób, że sędzia podejmuje decyzję własną, ignorując podstawowe zasady porządku prawnego. Nie można jednak zupełnie wykluczyć odstąpienia od zasady clara non sunt interpretanda, jeśli przemawiałyby za tym silne argumenty aksjologiczne ${ }^{36}$.

W 34 orzeczeniach SO w Częstochowie, odrzucając „wąsko rozumianą pozytywistyczną wizję poszukania «podstawy» rozstrzygnięcia”, wskazał na możliwość, a nawet konieczność stosowania konstytucji przez sądy. Jak podkreślił, w procesie orzeczniczym „ «liczy się» nie tylko «przepis» stanowiący bezpośrednią podstawę rozstrzygnięcia konkretnego sporu, ale i Konstytucja jako zwornik konstrukcyjny i aksjologiczny systemu prawa"37.

Krytykę judykatywy wzbudziła przypisywana pozytywizmowi teza o wyłączności wykładni językowej. „Przy wykładni rolą Sądu jest poszukiwanie celu regulacji i dążenie do uchwycenia sensu przepisu, nie zaś przeprowadzanie rachunku zdaniowego i absolutyzowanie literalnej, pozytywistycznej wykładni" ${ }^{38}$. Zdaniem SN ograniczenie wykładni operatywnej do wykładni językowej prowadzi do „przyjęcia koncepcji skrajnie pozytywistycznych” i „nie znajduje w dobie obecnej uzasadnienia" ${ }^{39}$.

W orzecznictwie można jednak znaleźć także próby obrony prymatu czy wręcz monopolu wykładni językowej z powołaniem się na „przyjętą w naszym systemie pozytywistyczną koncepcję systemu prawa" ${ }^{40}$.

Większość z obecnych w uzasadnieniach orzeczeń nawiązań do jusnaturalizmu dotyczy pojmowania i natury praw podstawowych jednostki. Jak zauważa SN, na obecny kształt praw człowieka wpłynęły „,przede wszystkim dociekania powstałej w XVII w. szkoły prawa natury oraz ustalenia francuskiej «Deklaracji Praw Człowieka i Obywatela» z dnia 26 sierpnia 1789 r." ${ }^{41}$.

36 Wyrok SA w Gdańsku z 16.07.2013 r. (I ACa 219/13), LEX nr 1372258.

37 Wyroki i postanowienia SO w Częstochowie z: 20.12.2019 r. (IV U 1386/19), LEX nr 2775673; 20.12 .2019 r. (IV U 1353/19), LEX nr 2775353; 20.12.2019 r. (IV U 1428/19), LEX nr 2773626; 18.12.2019 r. (IV U 1220/19), LEX nr 2772884; 18.12.2019 r. (IV U 1372/19), LEX nr 2772883; 18.12.2019 r. (IV U 1328/19), LEX nr 2771895; 13.12.2019 r. (IV U 1074/19), LEX nr 2785708; 6.12.2019 (IV U 564/19), LEX nr 2759048; 6.12.2019 r. (IV U 935/19), LEX nr 2764310; 6.12.2019 r. (IV U 1142/19), LEX nr 2770264; 6.12.2019 r. (IV U 886/19), LEX nr 2771896; 6.12.2019 r. (IV U 511/19), LEX nr 2775352; 2.12.2019 r. (IV U 599/19), LEX nr 2759047; 2.12.2019 r. (IV U 485/19), LEX nr 2761682; 2.12.2019 r. (IV U 460/19), LEX nr 2761683; 2.12.2019 r. (IV U 579/19), LEX nr 2761681; 25.10.2019 r., IV U 1607/19; 20.09.2019 r. (IV U 1195/19), LEX nr 2747474; 20.09.2019 r. (IV U 826/19), LEX nr 2729356; 8.08.2019 r., IV U 313/19; 30.07.2019 r., IV U 610/19; 30.07.2019 r. (IV U 699/19), LEX nr 2736481; 30.07.2019 r., IV U 99/19; 8.06.2018 r. (IV U 156/18), LEX nr 2741636; 8.06.2018 r. (IV U 41/18), LEX nr 2784313; 25.05.2018 r. (IV Pa 115/18), LEX nr 2519604; 24.03.2017 r. (IV U 1501/16), LEX nr 2292576; 10.03 .2017 r. (IV U 987/16), LEX nr 2265989; 21.10.2016 r. (IV U 1577/15), LEX nr 2149809; 21.10.2016 r. (IV U 1608/15), LEX nr 2149810; 8.04.2016 r. (IV U 1584/15), LEX nr 2024978; 17.04.2015 r. (IV U 170/15), LEX nr 2132634; 27.07.2012 r. (IV U 1820/11), LEX nr 1867686; 6.07.2012 r. (IV U 1746/11), LEX nr 1867685.

38 Wyrok SR dla Łodzi-Śródmieścia w Łodzi z 18.05.2016 r. (XIII GC 1079/15), LEX nr 2244110.

39 Postanowienie SN z 15.10.2014 r. (IV KK 190/14), LEX nr 1545107. O Powszechnej Deklaracji Praw Człowieka z 1948 r. jako „usankcjonowaniu odrodzenia praw naturalnych przez społeczność międzynarodową” zob. wyrok SA w Warszawie z 10.02.2005 r. (II AKa 440/04), OSA 2005/9, poz. 67.

40 Wyrok WSA w Gdańsku z 11.09.2008 r., I SA/Gd 254/08.

41 Wyrok SN z 28.09.2000 r. (V KKN 171/98), OSNKW 2001/3-4, poz. 31. 
Sądy odwołują się do jusnaturalizmu zwykle nie ex nomine ${ }^{42}$, lecz ujmując poszczególne prawa i wolności człowieka jako prawa „naturalne” czy „przyrodzone”, co znajduje swoją legitymizację w brzmieniu art. 30 ustawy zasadniczej ${ }^{43}$. Przykładowo, TK podnosi, że wolność sumienia ,jest wolnością tkwiącą w samej naturze człowieka, stąd określa się ją jako przyrodzoną, a przez to - niezbywalną (...) [W]olność ta bywa uznawana za ponadpozytywną, aksjologicznie związaną z samą naturą człowieka, będącą istotnym elementem jego godności" 44 .

Sądy nie są zgodne w przedmiocie katalogu praw naturalnych. Dla TK nie wszystkie prawa jednostki objęte zakresem art. 30 ustawy zasadniczej posiadają przymiot praw naturalnych. Jak zauważa:

Pośród praw, których źródłem jest art. 30 Konstytucji podstawowe znaczenie mają te, które nawiązując wprost do istoty godności ludzkiej, wyrażają jej kwintesencję, mają charakter praw fundamentalnych (...) Ustawodawca z reguły nie może ich nie tylko kwestionować, ale i ograniczać. Nie są one w zasadniczej swojej treści uzależnione od woli prawodawcy, a tym bardziej od organów stosujących prawo, bez względu na to, czy będą to organy administracji publicznej, czy sądy. Stąd określa się je mianem praw przyrodzonych ${ }^{45}$.

Inną dystynkcję czyni SN. Różnicuje „prawa” i „,wolności” jednostki, przypisując status prawnonaturalny jedynie tym drugim. W jego ocenie ,prawo człowieka”, w przeciwieństwie do „wolności człowieka”, posiada „charakter roszczenia do świadczenia ustalonego w akcie normatywnym. Powstaje ono z chwilą wejścia w życie normy prawnej, kreującej to prawo, nie jest więc prawem przyrodzonym i niezbywalnym"46.

Na kanwie nowelizacji prawa aborcyjnego, TK wskazał konsekwencje, jakie dla prawodawcy wiążą się z uznaniem partykularnego prawa za prawo przyrodzone. Podkreślił, że:

Uchylenie deklaracji, iż prawo do życia ma charakter przyrodzony, nie może być uznane za zmianę o charakterze normatywnym. Przyrodzony charakter danego prawa lub wolności nie jest bowiem zależny od woli ustawodawcy, a w związku z tym nie można cechy tej znieść aktem ustawowym (derogować) $)^{47}$.

O ile Konstytucja RP stanowi, że przyrodzona i niezbywalna godność człowieka jest źródłem wolności i praw człowieka, o tyle w orzecznictwie można spotkać stwierdzenie, że także sama godność osoby ludzkiej jest „prawem przyrodzonym”48. Innym razem TK określił „zasadę godności” jako „łącznik pomiędzy prawem naturalnym a prawem

42 Obok określeń „szkoła prawa natury” czy „doktryna prawa natury” w orzecznictwie pojawia się także termin „ideologia prawa natury”. Postanowienie TK z 7.05.2008 r. (SK 14/06), OTK-A 2008/4, poz. 66.

43 Zob. Wyrok Sądu Rejonowego (dalej: „SR”) w Toruniu z 6.08.2019 r. (I C 469/18), LEX nr 2736448.

${ }_{44}$ Wyrok TK z 7.10.2015 r. (K 12/14), OTK-A 2015/9, poz. 143. Zob. też jusnaturalistyczną charakterystykę innych praw i wolności: wyrok TK z 2.12.2009 r. (U 10/07), OTK-A 2009/11, poz. 163; wyrok TK z 21.07.2008 r. (P 49/07), OTK-A 2008/6, poz.108; orzeczenie TK z 30.01.1991 r. (K 11/90), OTK 1991/1, poz. 2; wyrok SN z 29.05.1996 r. (III ARN 96/95), OSNP 1996/24, poz. 366; wyrok SA w Szczecinie z 21.05.2019 r. (I AGa 5/19), LEX nr 2704173.

45 Wyroki TK z: 7.01.2004 r. (K 14/03), OTK-A 2004/1, poz. 1; 10.10.2001 r. (K 28/01), OTK 2001/7, poz. 212; 15.11.2000 r. (P 12/99), OTK 2000/7, poz. 260. O, prawach przyrodzonych naturze ludzkiej” zob. wyroki SA we Wrocławiu z: 15.06.2016 r. (II AKa 112/16), LEX nr 2061920; 11.03.2016 r. (II AKa 46/16), LEX nr 2023588; 4.11.2015 r. (II AKa 271/15), LEX nr 1957357.

46 Wyrok SN z 28.09.2000 r. (V KKN 171/98).

47 Orzeczenie TK z 28.05.1997 r. (K 26/96), OTK 1997/2, poz. 19.

48 Wyrok TK z 7.10.2015 r., K 12/14; wyroki SO we Wrocławiu z: 30.11.2018 r. (XII C 226/18), LEX nr 2613394; 17.12.2019 r. (XII C 2157/18), LEX nr 2842624. 
stanowionym"49. Z kolei sądy okręgowe w Częstochowie i Suwałkach wskazywały prawo naturalne jako jedno z możliwych ,źródeł godności jednostki”"50.

Niekiedy sądy nie klasyfikują poszczególnych uprawnień jako ius naturale, ale wskazują podobieństwo tych uprawnień do praw naturalnych, wzorowanie się na nich, wywodzenie się od nich lub ich treściową zbieżność. TK podniósł, że zasada swobody umów „ukształtowała się w XVIII i XIX w. pod wpływem liberalnego nurtu doktryny prawa natury” "51. Sąd Apelacyjny w Łodzi stwierdził, że: „Dobra osobiste nie wynikają z jakiegokolwiek aktu nabycia i trwają od narodzenia człowieka, aż do jego naturalnej śmierci, co zbliża je do praw naturalnych" ${ }^{52}$. W innym orzeczeniu ten sam sąd uznał, iż prawo własności jest „oparte na prawie naturalnym”53. W kolejnym wyroku wskazał, że wolność osobista „wynika z prawa naturalnego" ${ }^{54}$. Natomiast SA w Szczecinie zabójstwo dziecka przedstawił jako czyn jednocześnie bezprawny i ,zaprzeczający także prawom natury”55.

Sądy w prawie naturalnym doszukiwały się również źródła obowiązków prawnych. W jednym z orzeczeń SN stwierdził, że obowiązek rodzica ochrony dziecka przed zamachem na jego życie wynika nie tylko z art. 95 Kodeksu rodzinnego i opiekuńczego ${ }^{56}$, ale także ma umocowanie w ,prawie naturalnym albo w Prawie Natury”57.

Zdarzają się przypadki, gdy sąd kwestionuje prawnonaturalny charakter czy rodowód praw, obowiązków lub kompetencji, np. TK wskazał na nieprzystawalność koncepcji praw przyrodzonych do władzy samorządu terytorialnego, tłumacząc że: „Jednostki samorządowe wykonują władzę publiczną, która została im przekazana przez organy państwa, w związku z czym nie mają własnych zadań wywodzących się z praw naturalnych, które podlegałyby uznaniu lub akceptacji państwa"58.

Szczególnym przypadkiem nawiązania do szkoły prawa naturalnego w orzecznictwie jest wyrok SA w Katowicach uznający, że żona, która zamordowała męża nie nabywa po nim prawa do renty rodzinnej, pomimo tego, że de lege lata nie występuje - znany wcześniejszemu ustawodawstwu - przepis w brzmieniu: „Prawa do świadczeń albo do świadczeń w wyższym wymiarze nie nabywa osoba, która wywołała przestępstwem umyślnym okoliczności uzasadniające powstanie tego prawa”. Sąd brak takiego unormowania wytłumaczył tym, iż prawodawca najprawdopodobniej uznał, że: ,jest to tak powszechna norma wynikająca z prawa naturalnego i z Konstytucji, iż nie wymaga wprowadzenia do ustawy"59. Prawo naturalne stało się więc współpodstawą rozstrzygnięcia sprawy.

49 Wyrok TK z 9.07.2009 r. (SK 48/05), OTK-A 2009/7, poz. 108.

50 Wyroki i postanowienia SO w Częstochowie z: 25.10.2019 r. (IV U 1607/19); 20.09.2019 r. (IV U 826/19); 20.09 .2019 r. (IV U 1195/19); 8.08.2019 r. (IV U 313/19); 30.07.2019 r. (IV U 357/19), LEX nr 2731617; 30.07.2019 r. (IV U 699/19); 30.07.2019 r. (IV U 610/19); 30.07.2019 r. (IV U 99/19); 31.05.2019 r. (IV U 202/19), LEX nr 2735233; 31.05 .2019 r. (IV U 241/19); 18.03.2016 r. (IV U 1470/12), LEX nr 2132656; 20.12.2013 r. (IV U 1470/12), LEX nr 1867682; wyroki SO w Suwałkach z: 29.10.2019 r. (III U 819/19), LEX nr 2752612; 29.10.2019 r. (III U 789/19), LEX nr 2752617.

51 Wyrok TK z 29.04.2003 r. (SK 24/02), OTK-A 2003/4, poz. 33.

52 Wyrok SA w Łodzi z 11.12.2012 r. (I ACa 933/12), LEX nr 1313339. Z kolei SA w Warszawie mówi, że: „Pojęcie dóbr osobistych odnosi się do praw przyrodzonych”. Wyrok SA w Warszawie z 25.07.2019 r. (I ACa 137/19), LEX nr 2719392.

53 Wyrok SA w Łodzi z 17.07.2013 r. (I ACa 200/13), LEX nr 1349957.

54 Wyrok SA w Łodzi z 5.09.2013 r. (II AKa 132/13), LEX nr 1386138.

55 Wyrok SA w Szczecinie z 21.03.2013 r. (II AKa 29/13), LEX nr 1312172. Podobnie wyrok SO w Białymstoku z 4.12.2014 r. (III K 79/14), LEX nr 1883478.

56 Ustawa z 25.02.1964 r. - Kodeks rodzinny i opiekuńczy (tekst jedn.: Dz. U. z 2020 r. poz. 1359).

57 Postanowienie SN z 17.11.2005 r. (II KK 218/05), OSNKW 2006/2, poz. 17.

58 Wyrok TK z 26.05.2015 r. (Kp 2/13), OTK-A 2015/5, poz. 65.

59 Wyrok SA w Katowicach z 21.11.2006 r. (III AUa 1547/06), LEX nr 310411. Sprawa ta przejawia analogię do słynnej sprawy Riggs v. Palmer - przywołanej przez Ronalda Dworkina do scharakteryzowania istoty zasad prawa - gdzie sąd uznał, że wnuczek, który zamordował dziadka nie może po nim dziedziczyć. 
W orzecznictwie zdarzają się też próby wypośrodkowania pomiędzy pozytywizmem prawniczym a jusnaturalizmem. Wojewódki Sąd Administracyjny we Wrocławiu przyjął, że: „Granice, w których sędzia może się poruszać w ramach tzw. aktywizmu sędziowskiego to z jednej strony jest to skrajny pozytywizm i formalizm mający cechę legalności formalnej, z drugiej strony taki legalizm, który ma cechę sprawiedliwości i racjonalności, niegdyś nazywanej moralnością"60.

Rzadko sądy wprost nawiązują literalnie do innych kierunków filozoficzno-prawnych niż pozytywizm prawniczy i szkoła prawa naturalnego. Przypadki takie rozpoznano w uzasadnieniach 10 orzeczeń i dotyczyły one integralnej teorii prawa, hermeneutyki prawniczej, postmodernizmu prawniczego, ekonomicznej analizy prawa i feministycznej jurysprudencji.

Trzykrotnie w orzecznictwie administracyjnym sięgnięto do integralnej filozofii prawa R. Dworkina będącej „trzecią drogą w jurysprudencji” i „kompromisem pomiędzy pozytywizmem prawniczym a prawem natury”61. W myśl tej szkoły filozoficzno-prawnej „Orzecznictwo w systemie prawa stanowionego (...) stanowi tylko «historię interpretacyjną» danych regulacji prawnych, do której organ dokonujący ocen w zakresie stosowania i wykładni prawa powinien się ustosunkować" ${ }^{2}$.

W trzech orzeczeniach wzmiankowano hermeneutykę prawniczą. Wojewódzki Sąd Administracyjny w Warszawie wskazał, że: „hermeneutyczna teorii prawa (...) sprzeciwia się redukcji prawa tylko do tekstu” ${ }^{63}$, przypisując wykładni prawa „charakter kolisty”, gdzie „każdy fragment tekstu ma znaczenie tylko wówczas, gdy odniesiemy go do całości" ${ }^{64}$. Nie do końca zrozumiały jest natomiast fragment orzeczenia SA w Warszawie, w którym mowa o tym, że „zebrany w toku postępowania materiał dowodowy pozwala przyjąć, iż w przedmiotowej sprawie zachodzi (...) mechanizm [koła hermeneutycznego]"65. O ile w filozofii prawa koło hermeneutyczne odnosi się do przebiegu wykładni prawa, o tyle sąd w tych kategoriach przedstawił stan faktyczny sprawy.

Do szkoły postmodernizmu prawniczego nawiązał SA w Gdańsku, nie podzielając jednak deskryptywnie przywołanych założeń tego kierunku. Sąd ten zauważył, że sięganie do argumentów natury aksjologicznej w dyskursie prawniczym staje się obecnie utrudnione „wobec rozchwiania i kryzysu wielkich narracji”. W tym stanie rzeczy „Postmodernizm odkrywa na nowo sędziego interpretatora, którego przeciwstawia prawodawcy. Wolność sędziego znajduje nowe uzasadnienie. W sytuacji braku kategorii uniwersalnych, to właśnie dyskurs lokalny staje się źródłem sprawiedliwości" ${ }^{66}$. Sąd Okręgowy w Częstochowie wskazał z kolei, że w myśli ponowoczesnej „mówi się o wykładni prawa jako przemocy, o odrzuconym prawie" ${ }^{67}$.

Sąd Rejonowy w Gdyni za „absurdalne i niezasadne z perspektywy ekonomicznej analizy prawa" uznał interpretację art. $828 \S 1$ Kodeksu cywilnego ${ }^{68}$ prowadzącą do wniosku, że ubezpieczyciel nie może samodzielnie zorganizować dostępu

\footnotetext{
60 Wyroki WSA we Wrocławiu z: 26.04.2019 r. (I SA/Wr 1239/18), LEX nr 2673809; 21.03.2019 r. (I SA/Wr 1235/18), LEX nr 2656459.

${ }^{61}$ Wyrok WSA w Krakowie z 27.06.2012 r. (I SA/Kr 102/12), LEX nr 1266274.

62 Wyrok WSA w Warszawie z 6.02.2015 r. (III SA/Wa 916/14), LEX nr 1730415; wyrok NSA z 25.10.2012 r. (II FSK 290/11), POP 2014/1, poz. 63-67.

63 Wyrok WSA w Warszawie z 14.05.2007 r. (II SA/Wa 356/07), LEX nr 971973.

64 Wyrok WSA w Warszawie z 16.03.2018 r. (IV SA/Wa 3175/17), LEX nr 2559878.

65 Wyrok SA w Warszawie z 29.02.2016 r. (I ACa 735/15), LEX nr 2044271.

66 Wyrok SA w Gdańsku z 16.07.2013 r. (I ACa 219/13).

67 Postanowienie SO w Częstochowie z 20.12.2013 r. (IV U 1470/12).

68 Ustawa z 23.04.1964 r. - Kodeks cywilny (tekst jedn.: Dz. U. z 2020 r. poz. 1740).
} 
do samochodu zastępczego, a jedynie ma zawsze wyłącznie wypłacić odszkodowanie pokrywające poniesione przez poszkodowanego z tego tytułu koszty ${ }^{69}$.

Twierdzenie artykułowane na gruncie feministycznej jurysprudencji pojawia się w jednym z wyroków SN, aczkolwiek sąd za jego źródło wskazuje nie tyle feministyczną filozofię prawa, ile „ideologię feministyczną”. Sąd in concreto odnotował upatrywanie przez feminizm w pornografii źródeł krzywdy kobiet ${ }^{70}$.

\section{Jakościowa charakterystyka odwołań do szkół filozoficzno-prawnych w orzecznictwie}

Polskie sądy bardzo rzadko wypowiadają się wprost w przedmiocie zasadności i celowości sięgania w procesie orzeczniczym do argumentacji filozoficzno-prawnej czy filozoficznej in generale. Jeśli już podnoszą tę kwestię, to często dystansując się, a nawet ujawniając sceptycyzm wobec relewantności racji filozoficzno-prawnych i filozoficznych dla rozstrzygnięcia sprawy i uzasadnienia wyroku. Przykładowo TK interpretując pojęcie godności z art. 30 Konstytucji RP, zastrzegł, że: ,abstrahuje od toczonych na gruncie tego przepisu sporów zwolenników prawnonaturalnych i czysto pozytywistycznych koncepcji źródeł praw i wolności jednostki oraz filozoficznych źródeł inspiracji tej normy"71. Podobnie sędzia TK Mirosław Granat, omawiając w zdaniu odrębnym do jednego z orzeczeń dystynkcję na reguły i zasady prawa, zastrzegł, że wyjaśnienie różnic pomiędzy obiema kategoriami norm prawnych „nie jest intelektualnym ćwiczeniem z filozofii prawa, ale ostrzeżeniem przed radykalnym przewartościowaniem hierarchii zasad konstytucyjnych"72. Sąd Rejonowy w Słupsku uznał z kolei, że: „zagadnienia związane z filozofią prawa (...) znajdują się poza zakresem jurysdykcji"73.

Błędem byłoby jednak opieranie na powyższych cytatach konkluzji, że judykatywa kategorycznie dezawuuje doniosłość filozofii prawa dla procesu orzeczniczego. O mylności tej konkluzji zaświadcza już choćby to, że same sądy w uzasadnieniach orzeczeń powołują się na twierdzenia poszczególnych szkół filozoficzno-prawnych.

Sędziowie, aczkolwiek wciąż nieliczni, przejawiają świadomość tego, że ustalenia filozoficzno-prawne nie pozostają czymś stricte abstrakcyjnym czy nawet artefaktycznym, lecz są operacjonalizowalne w praktyce orzeczniczej i posiadają dla niej utylitarną wartość. „Nie oznacza to oczywiście, że filozofia prawa stanowi panaceum na bolączki i niedostatki prawa"74 i że z jej pomocą sądy zawsze dochodzą do prawidłowych rozstrzygnięć.

W rodzimym orzecznictwie nie stwierdzono wyraźnego nawiązania do realizmu prawnego, pomimo to że pozostaje on jedną z najbardziej wpływowych i rozpoznawalnych szkół filozoficzno-prawnych. Zapewne nieobecność odniesień do realizmu prawnego nie jest spowodowana niewiedzą o tym kierunku w środowisku prawniczym, zwłaszcza jeśliby mieć na względzie sędziów TK i SN. Wątpliwe jest też, aby sędziowie in gremio przyjmowali nieprzystawalność twierdzeń realizmu prawnego dla przebiegu procesu orzeczniczego. Brak wzmiankowania realizmu prawnego w sposób pośredni świadczy o tym, że pozytywizm prawniczy wciąż silnie naznacza postać praktyki orzeczniczej

69 Wyrok SR w Gdyni z 16.10.2017 r. (VI GC 394/16), LEX nr 2383655.

70 Wyrok SN z 23.11.2010 r. (IV KK 173/10), LEX nr 667510.

71 Wyrok TK z 28.06.2016 r. (K 31/15), OTK-A 2016, poz. 59.

72 Zdanie odrębne sędziego M. Granata do uzasadnienia wyroku TK z 30.09.2015 r. (K 3/13), OTK-A 2015/8, poz. 125.

73 Wyrok SR w Słupsku z 24.11.2017 r. (XIV K 413/16), LEX nr 2500286.

${ }^{74}$ J. Zajadło, Precedens rzeczywisty i pozorny, czyli po co prawnikom filozofia prawa, w: A. Śledzińska-Simon, M. Wyrzykowski (red.), Precedens w polskim systemie prawa, Warszawa 2010, s. 56. 
i determinuje mentalność środowiska sędziowskiego. Dla wielu sędziów tematem tabu jest przyznanie realności podziału na law in books oraz law in action, czy istnienie wpływu pozanormatywnych czynników na przebieg i rezultat procesu adjudykacyjnego.

Ilekroć sądy przywołują w uzasadnieniach szkoły filozoficzno-prawne, to zwykle czynią to abstrahując od wersji autorskich poszczególnych reprezentantów kierunku. Rzadko zatem w judykatach padają personalia przedstawicieli szkół filozoficzno-prawnych ${ }^{75}$. Sądy sięgają do właściwych dla konkretnych szkół założeń w ich „uśrednionej” postaci.

Wyłaniająca się z judykatów charakterystyka poszczególnych szkół filozoficzno-prawnych jest wysoce uproszczona, a nierzadko również, jak w przypadku pozytywizmu prawniczego, przejaskrawiona. Trudno kategorycznie przesądzić, czy symplistyczny i jednostronny obraz pozytywizmu w orzecznictwie odzwierciedla rzeczywisty stan wiedzy sędziów na temat szkoły pozytywizmu, czy też taka jego charakterystyka jest świadomym i celowym zabiegiem podporządkowanym argumentacji. W stosunku do niektórych orzeczeń - w których sądy mówią o „skrajnym” bądź „radykalnym” pozytywizmie - bardziej wiarygodne wydaje się być drugie wytłumaczenie. Sformułowania te suponują bowiem, że udziałem ich autorów jest świadomość istnienia pozytywizmu także w innej postaci, aczkolwiek założenia tego nie „radykalnego” czy nie „skrajnego” pozytywizmu nie są poddawane aproksymacji. W orzecznictwie na próżno szukać chociażby dystynkcji na pozytywizm twardy (ekskluzywny) i miękki (inkluzywny).

Niektóre krytyczne odwołania do pozytywizmu prawniczego sprawiają wrażenie „wyważania otwartych drzwi”. Sąd oponuje tym twierdzeniom, łączonym czy kojarzonym z pozytywizmem prawniczym, które żaden uznany współczesny przedstawiciel pozytywizmu nie artykułuje, np. będące rzekomo w opozycji do założeń pozytywizmu prawniczego poddawanie przepisów prawnych wykładni in generale czy niezawężanie interpretacji do wykładni językowej. Przykładowo, SN stwierdza, że jakkolwiek normy prawa ubezpieczeń społecznych „muszą być stosowane w zasadzie bez względu na pozatekstowy kontekst wartości aksjologicznych”, to zarazem „Nie oznacza to jednak nakazu ujmowania prawnych regulacji w sposób skrajnie pozytywistyczny, wyłączający dopuszczalność stosowania reguł prawniczej wykładni”. Sformułowanie to mylnie imputuje całkowite odrzucenie przez pozytywizm prawniczy wykładni prawa na rzecz bezpośredniego rozumienia przepisów ${ }^{76}$.

Czasami z kolei z przywoływanych twierdzeń przypisywanych partykularnym nurtom filozoficzno-prawnym sądy wyprowadzają zbyt daleko idące wnioski dla meritum procedowanych spraw. W tych kategoriach można postrzegać obwołanie przez sąd poszczególnych uprawnień mianem praw „przyrodzonych” czy „naturalnych”. Jak trafnie zauważa Andrzej Wróbel, prawnonaturalny charakter konkretnego uprawnienia nie znosi dopuszczalności i potrzeby jego prawnej pozytywizacji ${ }^{77}$.

W rozpatrywanych przed TK sprawach o konstytucyjność ustawowej reglamentacji praw i wolności człowieka kluczowe dla rozstrzygnięcia jest zweryfikowanie spełnienia przez prawodawcę przesłanek z art. 31 ust. 3 Konstytucji RP. Podkreślenie w uzasadnieniu orzeczenia jusnaturalistycznej natury tych praw i wolności - czego zasadniczo nie kwestionuje się

75 W trzech orzeczeniach w kontekście integralnej filozofii prawa wskazano na osobę R. Dworkina. W jednym orzeczeniu oraz dwóch zdaniach odrębnych nadmieniono postać H. Kelsena przy omawianiu odpowiednio postaci systemu prawa w ujęciu czystej teorii prawa oraz „tezy, że każda dowolna treść może być treścią prawa”. W kolejnym orzeczeniu wymieniono osobę J. Finnisa jako reprezentanta koncepcji prawa naturalnego. W jeszcze innym judykacie postmodernizm prawniczy połączono z osobą Michela Foucaulta.

76 Wyrok SN z 5.04.2005 r. (I PK 218/04), LEX nr 1298241.

77 Zdanie odrębne sędziego A. Wróbla do wyroku TK z 7.10.2015 r. (K 12/14). 
we współczesnej debacie polityczno-prawnej - posiada zapewne wartość edukacyjną, ale zarazem pozostaje w bardzo ograniczonym związku z racjonalizacją samego rozstrzygnięcia.

Większy potencjał szkoła prawa naturalnego posiada dla judykatywy w zakresie ustaleń walidacyjnych, w szczególności w sprawach trudnych (hard cases). W praktyce orzeczniczej przypadki zastosowania rozumowania wyrażanego formułą lex iniustissima non est lex wraz z powołaniem się na nią w uzasadnieniu orzeczenia są sporadyczne. Tymczasem, jak zauważa Jerzy Zajadło, historia ostatnich kilkudziesięciu lat dobitnie dowodzi, że wybór pomiędzy zasadą dura lex sed lex a lex iniustissima non est lex „nie jest wcale i wbrew wszelkim pozorom wyłącznie hipotetyczną mrzonką filozofów prawa"78.

Prawidłowość niektórych odwołań do szkół filozoficzno-prawnych w uzasadnieniach orzeczeń budzi wątpliwości. Sąd Rejonowy w Elblągu stwierdził, „że o słuszności wydawanych wyroków decyduje nie tylko słuszność stanowionego prawa, a więc walor pozytywizmu prawniczego zawarty w «sprawiedliwości legalnej», ale także słuszność wydawanych rozstrzygnięć («aequitas»)"79. Sąd mylnie łączy z pozytywizmem prawniczym słuszność prawa, skoro jednym z podstawowych założeń tej szkoły jest teza o rozdzieleniu prawa i moralności. Podobnie sprawiedliwość legalna abstrahuje od kategorii słuszności, a jej istotę wyraża paremia iustum quia iussum.

Źródłem konfuzji może też być stwierdzenie WSA w Warszawie, że: „Źródłem godności człowieka jest prawo naturalne, a nie tylko prawo stanowione". Podane brzmienie sugeruje, że prawo stanowione współkonstytuuje, obok prawa naturalnego, ludzką godność, co jest nieprawdą. Prawo stanowione nie jest „źródłem” godności człowieka, lecz tę godność potwierdza, gwarantuje i chroni. W kolejnym zdaniu swojego uzasadnienia WSA już prawidłowo zaznacza, że Konstytucja RP, określając godność jako cechę przyrodzoną każdego człowieka, tym samym komunikuje, iż godność ta „istnieje niezależnie od tego, czy prawo pozytywne da temu wyraz w swoich tekstach, czy też nie"80.

Problematyczna jest teza WSA we Wrocławiu, zgodnie z którą do uzasadnienia „trafności twierdzenia, że decyzja zgodna z orzecznictwem sądowym jest poprzez to zgodna z prawem” wystarczy odrzucić „teorię pozytywizmu prawniczego”, sprowadzającą źródła prawa do przepisów prawnych ${ }^{81}$. Prawomocne orzeczenie może być sprzeczne z prawem i to niezależnie od przyjmowanej teorii czy filozofii prawa.

Zdawkowy czy niepogłębiony charakter odwołań do szkół filozoficzno-prawnych w uzasadnieniach orzeczeń rodzi ambiwalentną ocenę. Z jednej strony, w niniejszej powściagliwości wyraża się trafne przekonanie sędziów o tym, że uzasadnienie nie może zastępować monografii bądź artykułu naukowego będących właściwymi miejscami dla czynienia wieloaspektowych rozważań z zakresu ogólnych nauk prawnych. Judykatywa odwołuje się do filozofii prawa nie w ramach doktrynalnego dyskursu, lecz w kontekście rozpoznania i rozstrzygnięcia konkretnych spraw, co poniekąd tłumaczy instrumentalne traktowanie dorobku filozofii prawa. Sięganie do poszczególnych szkół filozoficzno-prawnych podporządkowane jest celom klaryfikacyjnym (eksplanacyjnym) i perswazyjnym uzasadnienia. Z drugiej strony, jak słusznie zauważył K. Działocha, jedynie hasłowe wzmiankowanie poszczególnych twierdzeń formułowanych na gruncie filozofii prawa bez ich wyjaśnienia i dostatecznego rozwinięcia jest pozorowaną, a tym samym słabą argumentacją, którą łatwo podważyć.

78 J. Zajadło, Precedens..., s. 51.

79 Wyrok SR w Elblągu z 9.09.2015 r. (V GC 106/15), LEX nr 1928917.

80 Postanowienia WSA w Warszawie z: 6.03.2008 r. (III SA/Wa 309/08), LEX nr 1072694; 22.02.2008 r. (III SA/Wa 188/08), LEX nr 1071976.

81 Wyrok WSA we Wrocławiu z 29.09.2011 r. (II SA/Wr 567/11), LEX nr 1830534. 
Przypadki obecności odwołań do szkół filozoficzno-prawnych w uzasadnieniach orzeczeń do pewnego stopnia można rozpatrywać pod kątem stylu uzasadnienia. Nieuprawnione byłoby jednak uznanie, że nawiązanie do szkoły filozoficzno-prawnej w wyroku czy postanowieniu stanowi per se przejaw posłużenia się przez sąd tzw. stylem dyskursywnym. Za typowe dla tego stylu podaje się „,wskazanie różnych możliwych rozstrzygnięć poszczególnych kwestii cząstkowych, przytoczenie argumentów na rzecz każdego z możliwych rozstrzygnięć, uargumentowany wybór rozstrzygnięcia optymalnego" rujących, alternatywnych rozstrzygnięć interpretacyjnych" ${ }^{83}$. Komunikuje w ten sposób „że ma pole manewru i że służy mu wybór wśród kilku możliwości, z których wszystkie «dadzą się bronić» na tle tekstu, który posłużył mu jako podstawa rozstrzygnięcia" ${ }^{\prime 4}$.

Przeprowadzone studium orzecznictwa pokazuje, że sądy z reguły powołują się na ustalenia filozofii prawa nie po to, aby pokazać alternatywne czy konkurencyjne podejścia do rozwiązania konkretnej kwestii jurydycznej, ale przywołują to stanowisko filozoficzno-prawne, które argumentacyjnie wspiera wydane przez nich rozstrzygnięcie. Trudno na podstawie lektury tekstów orzeczeń ustalić, czy odzwierciedlają one rzeczywisty przebieg aktu sądowej deliberacji, czy też - jak ujęliby to realiści prawni - nawiązania do poszczególnych kierunków filozofii prawa w uzasadnieniu pełnią rolę wtórnej racjonalizacji sądowego werdyktu.

Gotowość odwołania się w uzasadnieniu orzeczenia do dorobku filozofii prawa może pozostawać w związku ze swoistym „zacięciem” filozoficzno-prawnym sędziego. Znamienny jest fakt, że wszystkie orzeczenia SO w Częstochowie, w których sąd sięga do ustaleń filozoficzno-prawnych zostały wydane personalnie przez tego samego sędziego.

Studium uzasadnień orzeczeń pokazuje świadomość filozoficzno-prawną także stron postępowania, a najprawdopodobniej ich pełnomocników procesowych, choć analiza judykatów pod tym kątem nie była celem niniejszego artykułu. Krytycznie należy się odnieść do stanu rzeczy, w którym sąd - w uzasadnieniu orzeczenia - jedynie sprawozdawczo odnotowuje argumentację filozoficzno-prawną strony. Klasyfikując twierdzenia strony jako „filozoficzne stanowisko” bądź „rozważania filozoficzne”, tym samym poczuwa się zwolniony z obowiązku jakiegokolwiek merytorycznego odniesienia się do nich ${ }^{85}$. W ten sposób implicite dezawuuje relewantność argumentacji tego typu dla procesu orzeczniczego. Czasami daje temu czytelny wyraz, np. przedstawiając filozoficzno-prawne i filozoficzne racje przywoływane przez strony postępowania w opozycji do ,wymiany rzeczowych argumentów, przystających do rozpoznawanej sprawy”86 czy „realnych okoliczności rozpoznawanego zdarzenia" ${ }^{87}$. Jak ujął to WSA w Krakowie, „ustosunkowując się do kwestii podniesionych przez autora skargi w duplice, to wskazać należy, że zaprezentowane tezy (...) jako poglądy filozoficznoprawne nie mogą być uwzględnione w procesie badania zgodności z prawem, zaskarżonej decyzji”" ${ }^{88}$. W pojedynczych przypadkach własne odniesienia sądu do szkół filozoficzno-prawnych były odpowiedzią na wcześniejsze odwołania strony czy jej pełnomocnika do ustaleń filozofii prawa.

\footnotetext{
M. Zieliński, Wyktadnia prawa. Zasady, reguty, wskazówki, Warszawa 2010, s. 264-265.

3 K. Płeszka, Wykładnia rozszerzająca, Warszawa 2010, s. 167.

4 E. Łętowska, Pozaprocesowe znaczenie uzasadnienia sq̨dowego, „Państwo i Prawo” 1997/5, s. 4.

85 Wyrok SA w Gdańsku z 2.12.2015 r. (I ACa 487/15), LEX nr 2152461; wyrok NSA z 30.03.2010 r. (II FSK 337/10), LEX nr 596397; wyrok WSA w Rzeszowie z 6.05.2011 r. (II SA/Rz 205/11), LEX nr 993690.

86 Wyrok SO w Elblągu z 17.10.2014 r. (IV Ua 40/14), LEX nr 1867534.

87 Wyrok SR w Jeleniej Górze z 5.11.2013 r. (II K 1029/12), LEX nr 1903578.

88 Wyrok WSA w Krakowie z 27.06.2012 r. (I SA/Kr 102/12).
} 


\title{
5. Podsumowanie
}

Rzadko w doktrynie prawniczej, nie tylko polskiej, wskazuje się na dopuszczalność, a nawet zasadność i potrzebę sięgania przez sędziów do argumentacji filozoficzno-prawnej, a tym bardziej dawania temu wyrazu w uzasadnieniach orzeczeń. Jakkolwiek rolą sądu nie jest „rozwiązywanie kwestii generalnych o charakterze filozoficznym”", to jednak filozofia prawa jest pomocna dla sędziów w rozstrzyganiu poszczególnych kwestii jurydycznych i uzasadnianiu tych rozstrzygnięć, zwłaszcza w hard cases. Ułatwia ona sędziemu „zrozumienie swojej roli oraz jej wypełnianie"

Przypadki literalnych odwołań do szkół filozoficzno-prawnych w uzasadnieniach orzeczeń pokazują, że przekonanie o doniosłości filozofii prawa dla procesu orzeczniczego i racjonalizacji jego rezultatów jest udziałem niektórych sędziów. Obecność w judykatach odniesień niniejszego typu nie stanowi jednak wartości samej w sobie. Ocena każdego przypadku sięgnięcia przez sąd do twierdzeń tego, czy innego kierunku filozoficzno-prawnego musi być dokonana przez pryzmat stanu faktycznego i/lub prawnego danej sprawy oraz pod kątem utylitarnego charakteru takiego odwołania dla celów argumentacji sędziowskiej. Nawiązania do szkół filozoficzno-prawnych w uzasadnieniach orzeczeń są redundantne, a nawet mogą stanowić źródło konfuzji, jeśli posiadają jedynie wymiar ornamentacyjny, eksponując rzekomą erudycję członków składu orzekającego. Posłużenie się przez sąd odniesieniem do ustaleń filozofii prawa powinno być podporządkowane funkcji eksplanacyjnej i perswazyjnej uzasadnienia. Wątpliwe, aby par excellence zdawkowe nawiązanie do szkół filozoficzno-prawnych mogło służyć zrealizowaniu tych funkcji. Od sądu nie można oczekiwać zrelacjonowania w uzasadnieniu wszystkich, czy nawet większości niuansów dyskursu filozoficzno-prawnego w jakiejś kwestii, ale można i należy wymagać, aby argumentacja filozoficzno-prawna, którą zdecydował się posłużyć, była ujęta w sposób rzetelny i komunikatywny, a nie jedynie powierzchowny.

\section{References to Schools of Legal Thought in the Justifications of Judgments of Polish Courts}

\begin{abstract}
The article presents the results of a quantitative and qualitative study of the Polish case law in terms of the presence of direct references to schools of legal thought in the written justifications of judgments. Although these types of references are very rare, their intensification can be observed in the last decade. In justifications of court decisions, references were made to just a few strands of jurisprudence. Most references relate to jusnaturalism and legal positivism. Courts characterize schools of legal thought in a simplified and exaggerated manner, and sometimes also incorrectly. The judicature usually disregards the authors' versions of particular strands of jurisprudence, reaching for the claims derived from these strands in their 'average' form. The paper posits that legal philosophy is potentially useful for courts, especially in hard cases. It may help judges to perform the explanatory and persuasive functions of justifications of judgments. The condition for this is that references to the tenets of specific schools of legal thought should not be superficial, shallow or slogan-like. Otherwise, they play only an ornamental role, not an argumentative one.
\end{abstract}

Keywords: schools of legal thought, justifications of judgments, Polish courts, judicial argumentation

89 Zdanie odrębne sędziego L. Garlickiego do pkt 3 sentencji orzeczenia TK z 28.05.1997 r. (K 26/96).

90 A. Barak, The Judge in a Democracy, Princeton 2006, s. 116. 


\section{BIBLIOGRAFIA / REFERENCES:}

Adachi, H. (2018). Radbruch and Fuller: Their Similarities and Differences. Philosophy of Law in Kanazawa, Japan, http://law-kanazawa.info/wp-content/uploads/2018/07/Adachi08July2018.pdf [last access: 10.12.2020].

Barak, A. (2006). The Judge in a Democracy. Princeton: Princeton University Press.

Dworkin, R. (2006). Imperium prawa. Warszawa: Wolters Kluwer.

Działocha, K., Gromski, W. (1995). Niepozytywistyczna koncepcja państwa prawnego a Trybunał Konstytucyjny. Państwo i Prawo 3, 4-16.

Eisgruber, C. (2008). Should Constitutional Judges be Philosophers? In S. Hershovitz (Ed.), Exploring Law's Empire: The Jurisprudence of Ronald Dworkin. Oxford: Oxford University Press.

Frankfurter, F. (1956). Of Law and Men. New York: Harcourt, Brace \& Co.

Grat, I.S. (2009). Stanowisko prawnonaturalne Czesława Strzeszewskiego na tle pogladów polskich tomistów. Białystok: Temida.

Kalisz, A., Stefaniuk, M. (2010). Filozofia prawa w polskiej edukacji prawniczej w pierwszej dekadzie XXI wieku. In A. Orłowska, P. Polaczuk, L. Świto (Ed.), Filozofia a praktyka prawnicza. Olsztyn: Wydawnictwo UWM.

Kotowski, A. (2016). Mętne, bo (czasem) muszą takie być. Dziennik Gazeta Prawna, https://prawo.gazetaprawna.pl/artykuly/957514,metne-bo-czasem-musza-takie-byc.html [last access: 10.12 .2020$]$.

Łączkowski, W. (1992). Filozofia prawa a instytucja Trybunału Konstytucyjnego. In B. Czech (Ed.), Filozofia prawa a tworzenie i stosowanie prawa. Katowice: Instytut Wymiaru Sprawiedliwości.

Łętowska, E. (1997). Pozaprocesowe znaczenie uzasadnienia sądowego, Państwo i Prawo 5, 3-17.

Maroń, G. (2018). Integralność religijna sędziego oraz argumentacja religijna $w$ amerykańskim procesie orzeczniczym. Rzeszów: Wydawnictwo Uniwersytetu Rzeszowskiego.

Morawski, L. (1994). Spór o pojęcie państwa prawnego. Państwo i Prawo 4, 3-12.

Najda, M., Romer, T. (2007). Etyka dla sędziów. Rozważania. Warszawa: Wolters Kluwer Polska.

Płeszka, K. (2010). Wykładnia rozszerzająca. Warszawa: Wolters Kluwer Polska.

Pound, C.W. (1929). Defective Law - Its Cause and Remedy. New York State Bar Association Bulletin 9, 279-288.

Potrzeszcz, J. (2007). Idea prawa w orzecznictwie polskiego Trybunatu Konstytucyjnego. Lublin: Wydawnictwo KUL.

Rundstein, S. (1937). Zagadnienia teorii prawa w orzecznictwie cywilnym Sądu Najwyższego. Palestra $12,1047-1056$.

Safjan, M. (2007). Wyzwania dla państwa prawa. Warszawa: Wolters Kluwer Polska.

Zajadło, J. (2010). Precedens rzeczywisty i pozorny, czyli po co prawnikom filozofia prawa. In A. Śledzińska-Simon, M. Wyrzykowski (Eds.), Precedens w polskim systemie prawa. Warszawa: Zakład Praw Człowieka. 
Zajadło, J. (2010). Sędzia konstytucyjny - profil filozoficznoprawny. In W. Staśkiewicz, T. Stawecki (Eds.), Dyskrecjonalność w prawie. Warszawa: LexisNexis.

Zajadło, J. (2008). Pięć minut antyfilozofii antyprawa. Glosa do uchwały SN z dnia 20 grudnia 2007 r., I KZP 37/07. Gdańskie Studia Prawnicze. Przeglad Orzecznictwa 1, 161-173.

Zajadło, J. (2008). Po co prawnikom filozofia prawa? Warszawa: Wolters Kluwer Polska.

Zieliński, M. (2010). Wykładnia prawa. Zasady, reguły, wskazówki. Warszawa: LexisNexis. 